\title{
Article \\ Proteomics of Muscle Microdialysates Identifies Potential Circulating Biomarkers in Facioscapulohumeral Muscular Dystrophy
}

\author{
Victor Corasolla Carregari ${ }^{1}$, Mauro Monforte ${ }^{2}$, Giuseppe Di Maio ${ }^{1}$, Luisa Pieroni ${ }^{3}$ (D), Andrea Urbani ${ }^{1}$, \\ Enzo Ricci ${ }^{2,4, *}$ and Giorgio Tasca ${ }^{2, *}$ (D)
}

Citation: Corasolla Carregari, V.; Monforte, M.; Di Maio, G.; Pieroni, L.; Urbani, A.; Ricci, E.; Tasca, G.

Proteomics of Muscle Microdialysates Identifies Potential Circulating Biomarkers in Facioscapulohumeral Muscular Dystrophy. Int. J. Mol. Sci. 2021, 22, 290.

https://doi.org/10.3390/ ijms22010290

Received: 29 October 2020

Accepted: 25 December 2020

Published: 30 December 2020

Publisher's Note: MDPI stays neutral with regard to jurisdictional clai$\mathrm{ms}$ in published maps and institutional affiliations.

Copyright: (C) 2020 by the authors. Licensee MDPI, Basel, Switzerland. This article is an open access article distributed under the terms and conditions of the Creative Commons Attribution (CC BY) license (https:// creativecommons.org/licenses/by/ $4.0 /)$.
1 Istituto di Biochimica e Biochimica Clinica, Università Cattolica del Sacro Cuore, 00168 Roma, Italy; corasolla@gmail.com (V.C.C.); giudimaio@hotmail.it (G.D.M.); andrea.urbani@policlinicogemelli.it (A.U.)

2 Unità Operativa Complessa di Neurologia, Fondazione Policlinico Universitario A. Gemelli IRCCS, 00168 Roma, Italy; mauro.monforte@gmail.com

3 Unità di Proteomica e Metabolomica, Fondazione S. Lucia IRCCS, 00179 Roma, Italy; 1.pieroni@hsantalucia.it

4 Istituto di Neurologia, Università Cattolica del Sacro Cuore, 00168 Roma, Italy

* Correspondence: enzo.ricci@policlinicogemelli.it (E.R.); giorgiotasca81@gmail.com (G.T.); Tel.: +39-06-30155869; Fax: +39-06-35501909

\begin{abstract}
Facioscapulohumeral muscular dystrophy (FSHD) is caused by a complex epigenetic mechanism finally leading to the misexpression of DUX4 in skeletal muscle. Detecting DUX4 and quantifying disease progression in FSHD is extremely challenging, thus increasing the need for surrogate biomarkers. We applied a shotgun proteomic approach with two different setups to analyze the protein repertoire of interstitial fluids obtained from 20 muscles in different disease stages classified by magnetic resonance imaging (MRI) and serum samples from 10 FSHD patients. A total of 1156 proteins were identified in the microdialysates by data independent acquisition, 130 of which only found in muscles in active disease stage. Proteomic profiles were able to distinguish FSHD patients from controls. Two innate immunity mediators (S100-A8 and A9) and Dermcidin were upregulated in muscles with active disease and selectively present in the sera of FSHD patients. Structural muscle and plasminogen pathway proteins were downregulated. Together with the upstream inhibition of myogenic factors, this suggests defective muscle regeneration and increased fibrosis in early/active FSHD. Our MRI targeted exploratory approach confirmed that inflammatory response has a prominent role, together with impaired muscle regeneration, before clear muscle wasting occurs. We also identified three proteins as tissue and possibly circulating biomarkers in FSHD.
\end{abstract}

Keywords: facioscapulohumeral muscular dystrophy; FSHD; inflammatory response; proteomics; biomarkers

\section{Introduction}

Facioscapulohumeral muscular dystrophy (FSHD) is one of the most common muscular dystrophies and is characterized by initial weakness of the facial, shoulder and upper arm muscles although potentially progressing to affect almost all skeletal muscles [1].

In its most prevalent form, it is associated with the deletion of a subset of D4Z4 microsatellite repeats in the subtelomeric region of chromosome $4 \mathrm{q}$ which allows, in the presence of a polyadenylation signal sequence, the stable expression of the DUX4 (double homeobox 4) retrogene. However, DUX4 protein and transcript levels cannot be easily measured in muscle tissue from FSHD patients [2], thus making the use of DUX4 as a biomarker unviable. The low level of its expression is in any case sufficient to determine several downstream molecular events, most notably including the activation of genes involved in germline and early stem cell development, innate immunity, and cancer testis antigens [3]. However, studies investigating the protein levels of these downstream targets in skeletal muscle and serum of FSHD patients are currently lacking. 
Since FSHD presents a chronic, slow and highly variable clinical progression, proving the efficacy of a drug in a clinical trial is challenging [4]. Circulating biomarkers that reflect the degree of pathology could provide a quick, objective, and quantitative assessment of disease severity, allowing meaningful changes to be detected in a time period when functional changes may not yet be appreciated. Since all the muscles are exposed to the circulation, muscle derived serum proteins should theoretically reflect an average disease burden throughout the body.

To date, limited data are available on peripheral blood biomarkers in FSHD. Two pilot studies using commercially available multiplex assays [5] and high-throughput proteomic platforms [6] have identified an overrepresentation of a small number of proteins mostly related to unspecific muscle damage in FSHD sera compared with controls. While this manuscript was under revision, another study characterized plasma samples of individuals affected by early-onset FSHD using different -omics techniques [7], detecting a panel of miRNAs and the protein S100-A8 as candidate disease biomarkers.

Using muscle magnetic resonance imaging (MRI) to investigate FSHD, areas characterized by increased signal on short tau inversion recovery (STIR) sequences, accounting for muscle edema, were found in muscles not yet replaced by fat [8]. Following patients up over time, it is possible to appreciate an evolution towards fatty replacement of STIR hyperintense (STIR+) lesions [9]. STIR+ lesions are therefore considered a potential marker of disease activity in FSHD [10].

We previously conducted a microdialysis study on FSHD patients to identify the inflammatory cytokines present in the skeletal muscle intercellular milieu, using a multiplex assay analysis [11]. Microdialysis is a mini-invasive molecular sampling procedure performed with the introduction of a cylindrical semi-permeable membrane into the medium of interest, allowing a continuous molecular sampling of the interstitial fluid (Figure 1).

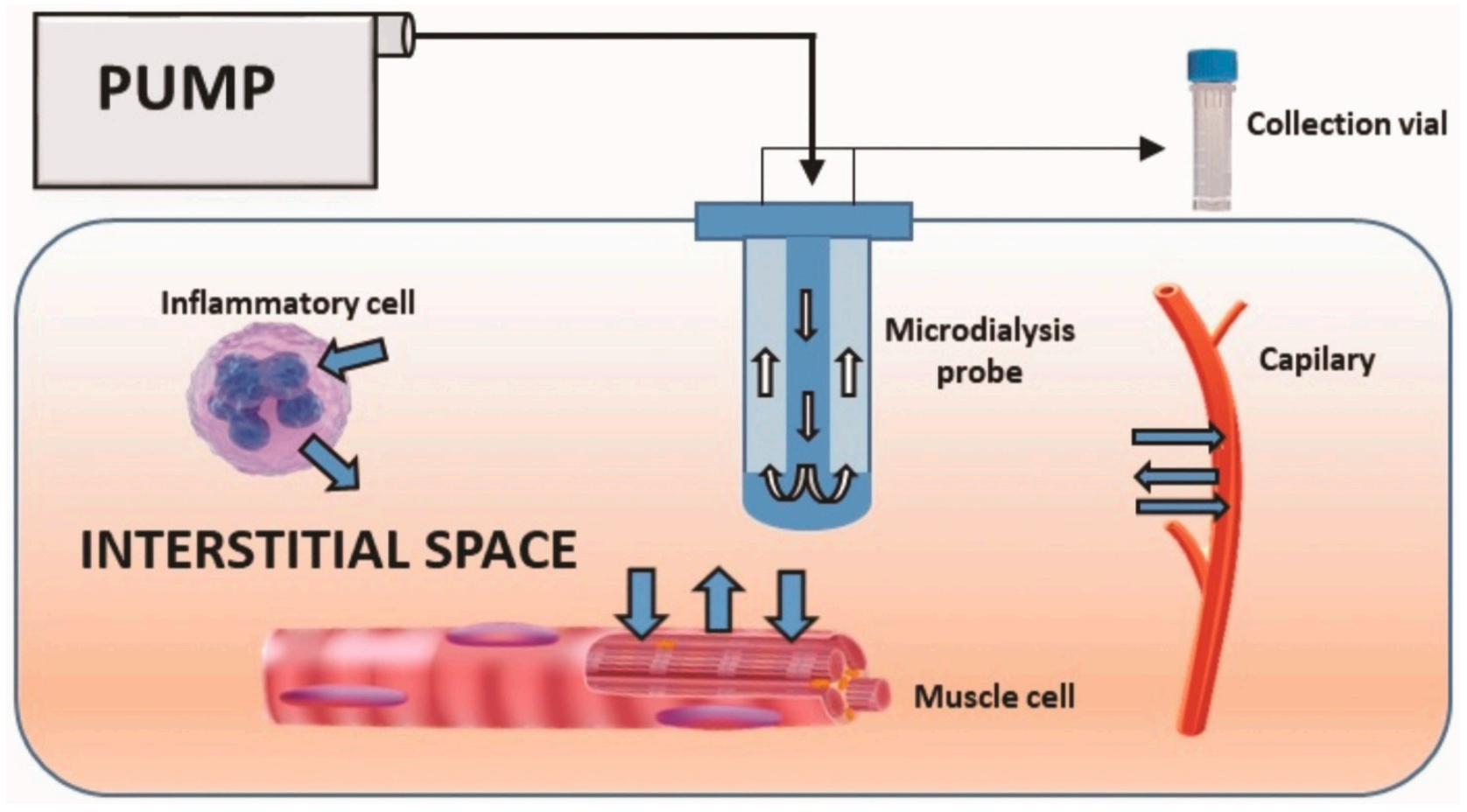

Figure 1. Schematic representation of the microdialysis system.

We implemented a protocol using high cut-off membranes (100 kDa) targeting muscles with different MRI features (STIR+ and contralateral STIR-), simultaneously in the same patients (Figure 2). A summary of the characteristics of the population studied is reported in Table 1. 


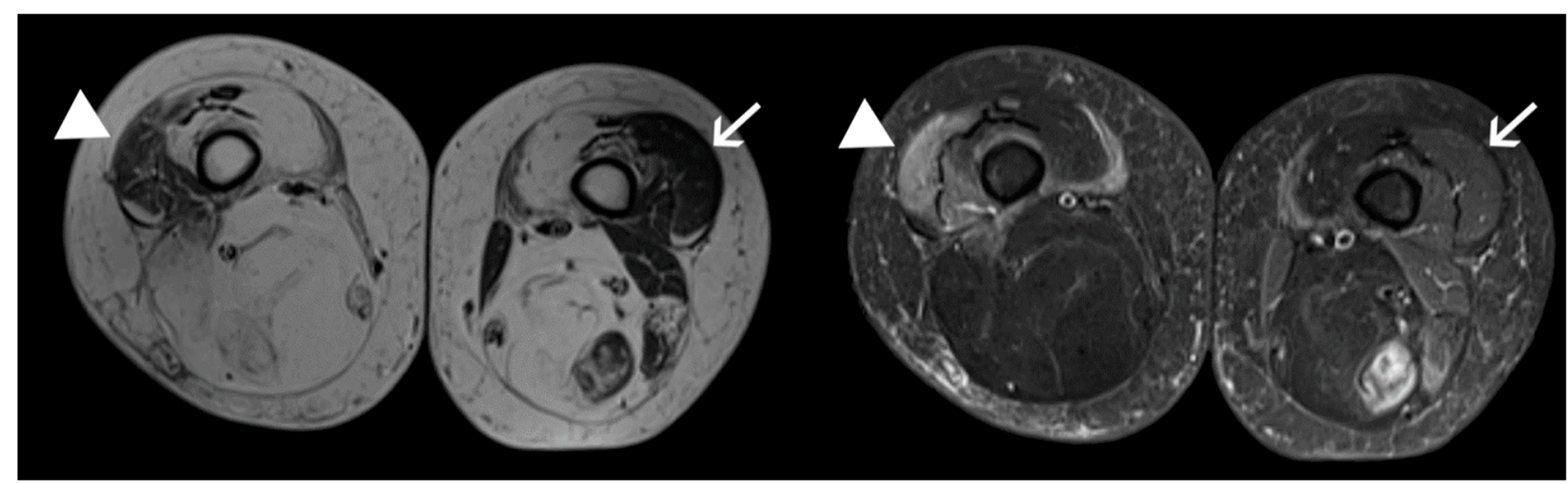

Figure 2. Muscles sampled by microdialyisis. STIR+ (arrowhead) and STIR- (arrow) vastus lateralis muscles sampled in the same patient. Axial STIR sequences of the thigh muscles are shown on the right-hand side, with corresponding T1-weighted images on the left.

Table 1. Summary of the characteristics of study participants. Age is reported as mean \pm standard deviation; for EcoRI fragment length (in $\mathrm{kb}$ ) and Clinical Severity Scale (CSS) the median value is indicated. $\mathrm{M}=$ males, $\mathrm{F}=$ females.

\begin{tabular}{cccccc}
\hline CATEGORY & $n$ & AGE & SEX & EcoRI & CSS \\
\hline FSHD & 10 & $41.7 \pm 13.4$; range 18-58 & $5 \mathrm{M}-5 \mathrm{~F}$ & 21.5; range 15-25 & 3 ; range 1.5-3.5 \\
\hline CONTROLS & 4 & $41.5 \pm 16.4$; range 24-60 & $3 \mathrm{M}-1 \mathrm{~F}$ & - & - \\
\hline
\end{tabular}

In this work we used muscle interstitial fluid samples collected by microdialysis to look more broadly at the composition of the extracellular milieu. We applied a holistic approach, by means of shotgun proteomics, to characterize and compare the whole protein set present in the different samples, followed by a targeted approach trying to identify known DUX4 targets at the protein level. Finally, we analyzed the protein signature of serum samples from the same patients.

\section{Results}

\subsection{Combined Proteomic Analysis of Microdialysates}

We identified by Data Independent Acquisition (DIA) a total of 1156 proteins of which 344 were shared among all the conditions, 130 were found only in the samples from the STIR+ muscles, 125 only in STIR-, 148 in controls and 57 in the non-penetrant gene carrier (NPGC) (Figure 3A; Supplementary Table S1). To increase the robustness of data, microdialysate samples from 3 STIR+, 3 STIR-, and 3 control muscles were submitted to a different setup of analysis in Data Dependent Acquisition (DDA) mode. A total of 578 proteins were identified with high confidence (Supplementary Table S2). Comparing the identified proteins obtained from both of mass spectrometers we observed a broad overlap, since $67 \%$ of the proteins identified by DDA were also covered by DIA (Figure 3B).

A functional classification analysis using PANTHER was performed on the whole list of identified proteins. The classification according to the Gene Ontology (GO) term Cellular Component showed that the proteins recovered in the microdialysates mostly belonged to the extracellular space component confirming their secretory origin, in accordance with the provenience of the samples (Figure 3C). Nucleic acid binding (16\%), enzyme modulator $(11.6 \%)$ and defense immunity $(9.6 \%)$ were found to be among the most populated subgroups of the functional classification according to the GO term Protein Class (Figure 3D). 
A
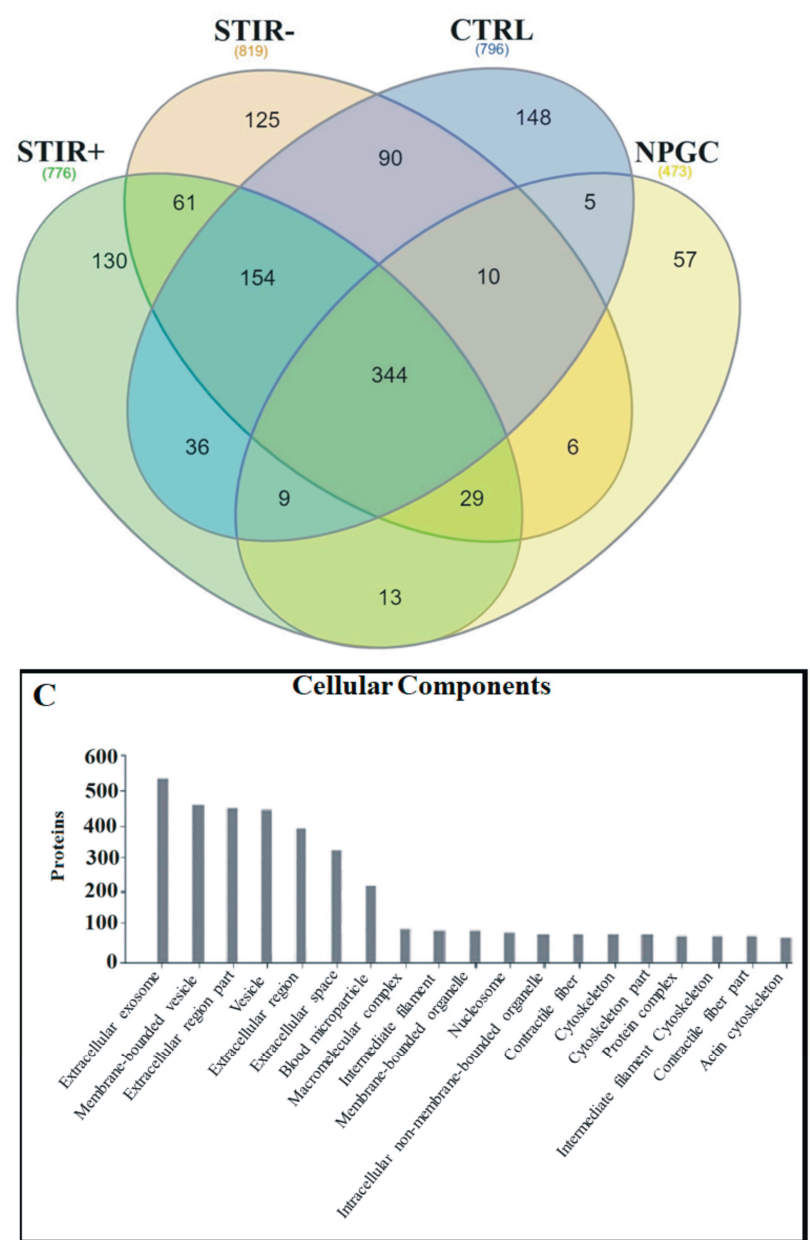
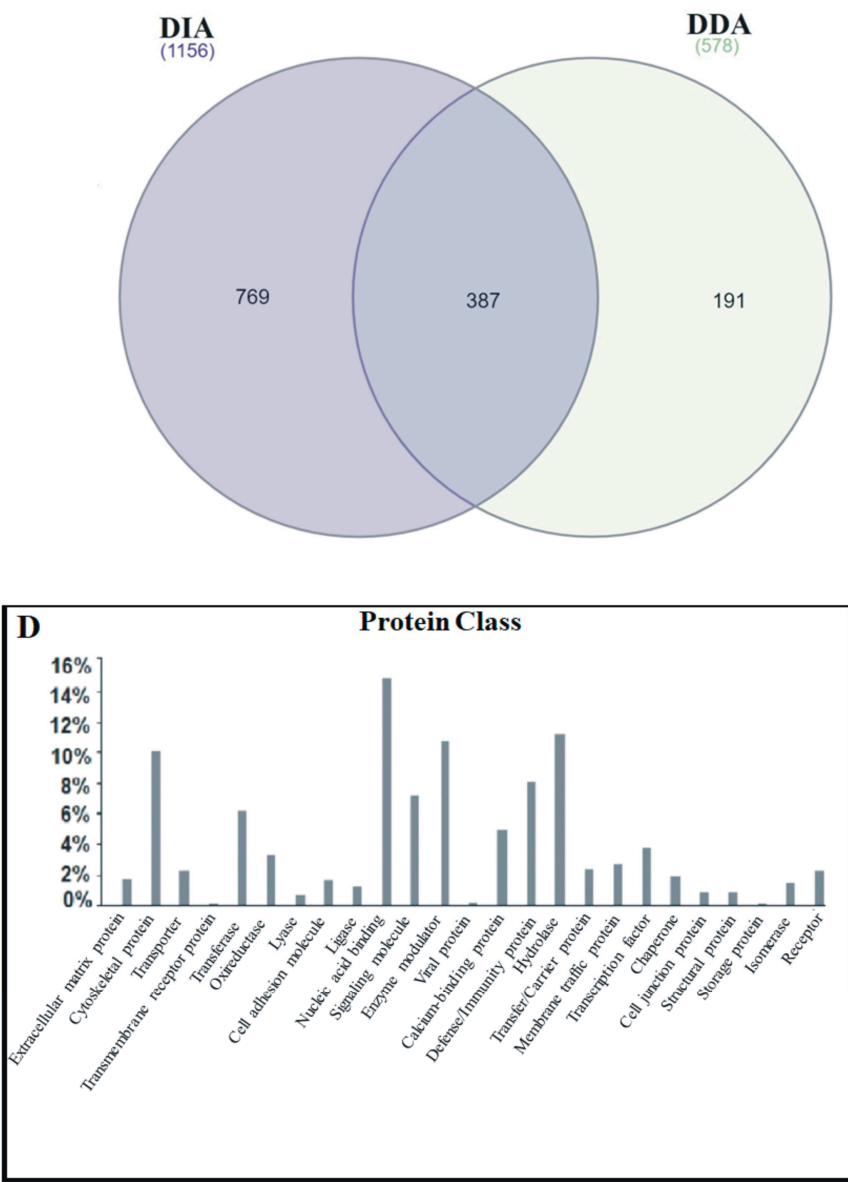

Figure 3. Identified proteins and Gene Ontology analysis. (A) Venn diagram of all the proteins identified in DIA in the examined conditions. (B) Overlap between proteins identified with the Synapt G2Si (DIA) and Orbitrap Elite (DDA) mass spectrometers. (C) PANTHER Gene Ontology analysis showing the cellular components to which the identified proteins belong. (D) PANTHER Gene Ontology analysis showing the class distribution of the identified proteins.

\subsection{Comparative Proteomic Analysis Using DIA: STIR+ Versus STIR-Muscles}

Using a label free method, we quantified and identified dysregulated proteins in STIR+ compared with STIR- muscles. We found 21 proteins upregulated in STIR+ muscles (fold change higher than 20\%). Among those, Prostaglandin-H2 D-isomerase (P41222), Protein S100-A9 (P06702), Insulin-like growth factor-binding protein 4 (P22692), Dermcidin (P81605), and several Immunoglobulin kappa fragments showed an upregulation higher than $50 \%$.

On the contrary, 29 proteins, mainly represented by structural muscle proteins, were found downregulated in STIR+ muscles (Table 2).

Table 2. Comparison of protein level expression between STIR+ and STIR-samples, shown as ratio.

\begin{tabular}{|c|c|c|c|}
\hline Accession Number & Protein Description & Score & STIR+:STIR- Ratio \\
\hline P41222 & Prostaglandin-H2 D-isomerase (PTGDS) & 661.92 & 2.89 \\
\hline P06702 & Protein S100-A9 (S100A9) & 4710.25 & 2.23 \\
\hline P22692 & Insulin-like growth factor-binding protein 4 (IGFBP4) & 450.89 & 1.80 \\
\hline P81605 & Dermcidin (DCD) & 3227.52 & 1.77 \\
\hline A2NJV5 & Immunoglobulin kappa variable 2-29 (IGKV2-29) & 2955.26 & 1.67 \\
\hline
\end{tabular}


Table 2. Cont.

\begin{tabular}{|c|c|c|c|}
\hline Accession Number & Protein Description & Score & STIR+:STIR- Ratio \\
\hline A0A075B6S2 & Immunoglobulin kappa variable 2D-29 (IGKV2D-29) & 2955.26 & 1.65 \\
\hline A0A075B6P5 & Immunoglobulin kappa variable 2-28 (IGKV2-28) & 2955.26 & 1.65 \\
\hline P06310 & Immunoglobulin kappa variable 2-30 (IGKV2-30) & 2955.26 & 1.63 \\
\hline A0A0A0MRZ7 & Immunoglobulin kappa variable 2D-26 (IGKV2D-26) & 2955.26 & 1.63 \\
\hline A0A075B6S6 & Immunoglobulin kappa variable 2D-30 (IGKV2D-30) & 2955.26 & 1.62 \\
\hline P01615 & Immunoglobulin kappa variable 2D-28 (IGKV2D-28) & 2955.26 & 1.62 \\
\hline P01614 & Immunoglobulin kappa variable 2D-40 (IGKV2D-40) & 3081.8 & 1.62 \\
\hline A0A087WW87 & Immunoglobulin kappa variable 2-40 (IGKV2-40) & 3081.8 & 1.58 \\
\hline P05109 & Protein S100-A8 (S100A8) & 3410.17 & 1.42 \\
\hline P01619 & Immunoglobulin kappa variable 3-20 (IGKV3-20) & $11,910.68$ & 1.42 \\
\hline P02766 & Transthyretin (TTR) & $21,752.78$ & 1.34 \\
\hline P02790 & Hemopexin (HPX) & $10,037.44$ & 1.31 \\
\hline P11217 & Glycogen phosphorylase_muscle form (PYGM) & 669.66 & 1.26 \\
\hline P07998 & Ribonuclease pancreatic (RNASE1) & 3437.69 & 1.26 \\
\hline P11216 & Glycogen phosphorylase_brain (PYGB) & 632.03 & 1.25 \\
\hline P02652 & Apolipoprotein A-II (APOA2) & $18,158.41$ & 1.23 \\
\hline P59665 & Neutrophil defensin 1 (DEFA1) & 3886.69 & 0.81 \\
\hline P59666 & Neutrophil defensin 3 (DEFA3) & 3886.69 & 0.79 \\
\hline P62937 & Peptidyl-prolyl cis-trans isomerase A (PPIA) & 891.54 & 0.73 \\
\hline Q9H299 & $\begin{array}{l}\text { SH3 domain-binding glutamic acid-rich-like protein } 3 \\
\text { (SH3BGRL3) }\end{array}$ & 2135.99 & 0.73 \\
\hline P61626 & Lysozyme C (LYZ) & 6273.03 & 0.71 \\
\hline P02042 & Hemoglobin subunit delta (HBD) & $29,240.84$ & 0.71 \\
\hline P07451 & Carbonic anhydrase 3 (CA3) & 1277.63 & 0.70 \\
\hline P0CG47 & Polyubiquitin-B (UBB) & 685.65 & 0.69 \\
\hline P62987 & Ubiquitin-60S ribosomal protein L40 (UBA52) & 685.65 & 0.68 \\
\hline P62979 & Ubiquitin-40S ribosomal protein S27a (RPS27A) & 690.87 & 0.67 \\
\hline P0CG48 & Polyubiquitin-C (UBC) & 685.65 & 0.67 \\
\hline P68871 & Hemoglobin subunit beta (HBB) & $67,024.84$ & 0.65 \\
\hline P69905 & Hemoglobin subunit alpha (HBA1) & $28,016.07$ & 0.65 \\
\hline P02671 & Fibrinogen alpha chain (FGA) & 3726.94 & 0.63 \\
\hline P06727 & Apolipoprotein A-IV (APOA4) & 3903.4 & 0.59 \\
\hline P00747 & Plasminogen (PLG) & 2244.15 & 0.57 \\
\hline P02100 & Hemoglobin subunit epsilon (HBE1) & 1198.27 & 0.48 \\
\hline P07737 & Profilin-1 (PFN1) & 8113.64 & 0.47 \\
\hline A5A3E0 & POTE ankyrin domain family member F (POTEF) & 354.23 & 0.43 \\
\hline Q02325 & Plasminogen-like protein B (PLGLB1) & 895.85 & 0.42 \\
\hline Q6S8J3 & POTE ankyrin domain family member E (POTEE) & 363.36 & 0.42 \\
\hline P69891 & Hemoglobin subunit gamma-1 (HBG1) & 2857.95 & 0.41 \\
\hline P63261 & Actin_cytoplasmic 2 (ACTG1) & 2756.19 & 0.40 \\
\hline P60709 & Actin_cytoplasmic 1 (ACTB) & 2756.19 & 0.40 \\
\hline P69892 & Hemoglobin subunit gamma-2 (HBG2) & 2888.5 & 0.39 \\
\hline
\end{tabular}


Table 2. Cont

\begin{tabular}{cccc}
\hline Accession Number & Protein Description & Score & STIR+:STIR- Ratio \\
\hline P68032 & Actin_alpha cardiac muscle (ACTC1) & 1401.05 & 0.33 \\
\hline P63267 & Actin_gamma-enteric smooth muscle (ACTG2) & 1401.05 & 0.32 \\
\hline P62736 & Actin_aortic smooth muscle (ACTA2) & 1401.05 & 0.32 \\
\hline P68133 & Actin_alpha skeletal muscle (ACTA1) & 1401.05 & 0.32 \\
\hline
\end{tabular}

Only proteins with more than $20 \%$ fold-change are listed. Score is calculated through the combined scores of all identified mass spectra that can be overlaid to amino acid sequences within each protein. Higher scores indicate a more confident match (ProteinLynx Global Server, PLGS, cutoff score: 4.5$)$. Only proteins with $p$-value $\leq 0.05$ are shown.

The heatmap of all the STIR+, STIR- and control samples showed that controls were gathered together and displayed clearly higher similarity to STIR- than STIR+ samples. Nine out of 10 STIR+ samples also clustered in the same group. Three STIR- samples (P6, P11 and, to a lesser extent, P7) clustered close to their correspondent STIR+ (Figure 4).

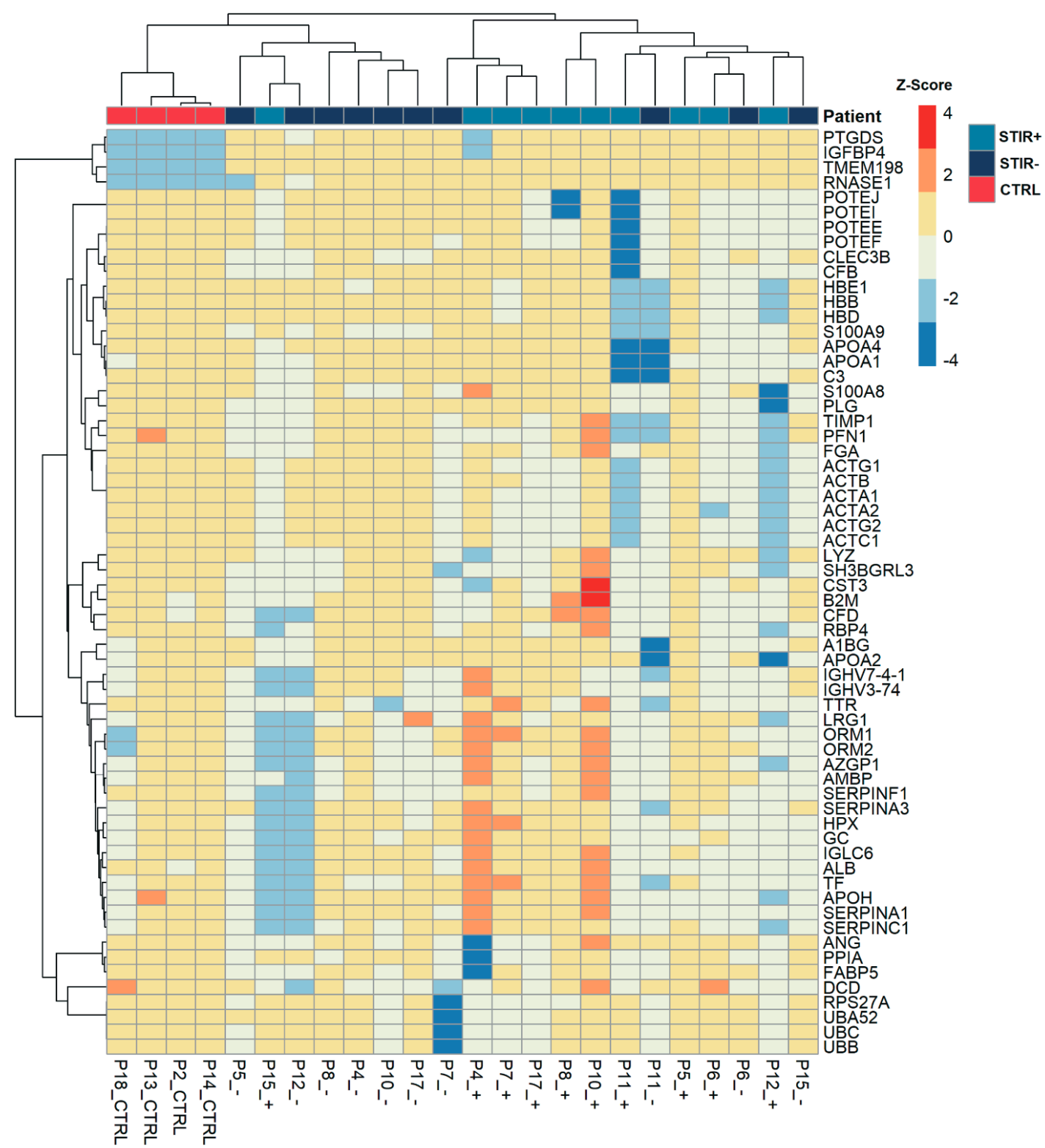

Figure 4. Heatmap showing the expression level of the proteins in STIR+, STIR- and control samples. 
The paired analysis of samples obtained from the STIR+ and contralateral STIRmuscle of the same patient confirmed a significant dysregulation of eight proteins (Supplementary Figure S1). Other proteins of possible interest, such as components of complement system (Complement C1q subcomponent subunit B (P02746); Complement C1r subcomponent (P00736); Complement C1s subcomponent (P09871); Complement component C8 gamma (P07360) and beta (P07358) chains) [12] were identified only in a in small number of STIR+ samples; several C-C motif chemokines $(14,18,21$, and 27) were also upregulated in the STIR+ samples analyzed, even if not reaching statistical significance (Supplementary Table S3).

Ingenuity pathway analysis (IPA) revealed that dysregulated proteins in STIR-versus STIR+ samples predict the activation in STIR- muscles of MRTFA (myocardin related transcription factor A), MRTFB (myocardin related transcription factor B), SRF (serum response factor), and NFE2L2 (nuclear factor, erythroid 2 like 2), a master regulator of antioxidant response in injury and inflammation (Supplementary Table S4). On the contrary, IFNG (interferon gamma) is predicted to be inhibited in STIR- compared with STIR+ muscles. IPA also showed modulations in the inflammatory response, metabolic, and developmental pathways (Supplementary Table S5; Figure S2A).

\subsection{Comparison between STIR+Muscles and Controls}

A total of 84 proteins were dysregulated of which 30 showed an upregulation in STIR+ muscles, while 54 were downregulated. The upregulated proteins were mainly involved in complement and coagulation cascades and innate immune response. The quantitative analysis confirmed a downregulation in STIR + muscles of several structural muscle proteins, consistently with the signs of early damage seen on MRI, of proteins related with the plasminogen pathway (Plasminogen, Plasminogen-like protein B and Vitronectin), as well as of Neutrophil defensin 1 and 3 (Supplementary Table S6).

IPA showed that the protein regulation in STIR+ muscles could be affecting among others the clathrin-mediated endocytosis and LXR/RXR activation pathways (Supplementary Table S5). The upstream activation analysis suggested a possible regulation of the genes SRF, NOS2 (nitric oxide synthase 2), MYOD1 (myogenic differentiation 1), and IL6 (interleukin 6) (Supplementary Table S4). Finally, network analysis supported an alteration of skeletal muscle system development and function and inflammatory response (Supplementary Figure S2B).

\subsection{Comparison between STIR-Muscles and Controls}

In total, 135 proteins were differentially regulated. Several of the proteins upregulated in STIR+ were also found upregulated in STIR- patients compared to controls (Supplementary Table S7). Insulin-like growth factor II (P01344) was found only in the STIR- muscles; Fatty acid binding protein_adipocyte (P15090) was six-fold more expressed in STIR- samples, while Complement factor D (P00746) and Flavin reductase (P30043) were three-fold more expressed. Structural muscle proteins were downregulated also in the STIR- samples, although to a lesser extent than in STIR+ samples.

Upstream analysis confirmed regulation of pathways overlapping with the STIR+ versus control comparison. We found a predicted activation of KDM5A (lysine demethylase 5A) and a predicted inhibition of MYOCD (myocardin), IPMK (inositol polyphosphate multikinase) and $M E F 2 C$ (myocyte enhancer factor 2C), that are genes involved in myogenesis and muscle differentiation (Supplementary Table S4). IPA Network analysis confirmed the association of the dysregulated proteins in STIR- muscles with cellular assembly and organization, muscle development and function (Supplementary Figure S2C). When the NPGC sample was analyzed using the same parameters of quantitative analysis and compared to all the other conditions, it showed greater similarity with controls and only four unique proteins were identified (Supplementary Table S3). 


\subsection{DDA Label Free Quantification}

Among the 578 proteins identified, 31 were differentially expressed in STIR+ compared to the STIR- and control samples, the majority being upregulated $\geq 30 \%$ (Table 3 ). Most of dysregulated proteins in both DDA and DIA, such as Beta-2-microglobulin (P61769), S100-A8 (P05109), A9 (P06702), Dermcidin (P81605), and Transthyretin (P02766), were significantly upregulated in STIR+ muscles. Structural muscle fiber proteins were consistently downregulated in samples from STIR+ muscles also in the DDA mode.

Table 3. Label free analysis of proteins identified by DDA.

\begin{tabular}{|c|c|c|c|c|c|c|c|c|}
\hline $\begin{array}{l}\text { Accession } \\
\text { Number }\end{array}$ & Protein Description & $\begin{array}{l}\text { PSMs } \\
\text { STIR+ }\end{array}$ & $\begin{array}{l}\text { PSMs } \\
\text { STIR- }\end{array}$ & $\begin{array}{l}\text { PSMs } \\
\text { CTRL }\end{array}$ & $\begin{array}{l}\text { Fold Change } \\
\text { STIR+/STIR- }\end{array}$ & $\begin{array}{l}\text { Fold Change } \\
\text { STIR+/CTRL }\end{array}$ & $\begin{array}{c}p \text { Value } \\
\text { STIR+/STIR- }\end{array}$ & $\begin{array}{c}p \text { Value } \\
\text { STIR+/CTRL }\end{array}$ \\
\hline Q8NE71 & $\begin{array}{l}\text { ATP-binding cassette } \\
\text { sub-family } \\
\text { F member } 1 \text { (ABCF1) }\end{array}$ & 3.5 & 1 & 1 & 3.5 & 3.5 & 0.007 & 0.007 \\
\hline P13796 & Plastin-2 (LCP1) & 4 & 1 & 12.5 & 4 & -3.13 & & 0.003 \\
\hline Q14019 & $\begin{array}{c}\text { Coactosin-like protein } \\
\text { (COTL1) }\end{array}$ & 4 & 1 & 6.5 & 4 & -1.63 & & 0.038 \\
\hline P61769 & $\begin{array}{l}\text { Beta-2-microglobulin } \\
\text { (B2M) }\end{array}$ & 27 & 14 & 11.5 & 1.93 & 2.35 & 0.012 & 0.029 \\
\hline P04040 & Catalase (CAT) & 35.5 & 16 & 8.5 & 2.22 & 4.18 & 0.040 & 0.017 \\
\hline P81605 & Dermcidin (DCD) & 19 & 8.5 & 13 & 2.24 & 1.46 & 0.020 & \\
\hline O75223 & $\begin{array}{l}\text { Gamma-glutamylcclo } \\
\text { transferase (GGCT) }\end{array}$ & 9.5 & 3 & 3 & 3.17 & 3.17 & 0.006 & 0.006 \\
\hline P15924 & Desmoplakin (DSP) & 65.5 & 29.5 & 7.5 & 2.22 & 8.73 & 0.137 & 0.026 \\
\hline P22352 & $\begin{array}{c}\text { Glutathione } \\
\text { peroxidase } 3(\mathrm{GPX} 3)\end{array}$ & 4.5 & 1 & 1 & 4.5 & 4.5 & 0.003 & 0.003 \\
\hline P04433 & $\begin{array}{l}\text { Ig kappa chain V-III } \\
\text { region VG (Fragment) }\end{array}$ & 11 & 5 & 5 & 2.2 & 2.2 & & 0.027 \\
\hline P69905 & $\begin{array}{l}\text { Hemoglobin subunit } \\
\text { alpha (HBA1) }\end{array}$ & 182 & 56 & 74 & 3.25 & 2.46 & 0.042 & 0.027 \\
\hline P01743 & $\begin{array}{l}\text { Ig heavy chain V-I } \\
\text { region HG3 }\end{array}$ & 9.5 & 4,5 & 7 & 2.11 & 1.36 & 0.019 & 0.038 \\
\hline P01767 & $\begin{array}{c}\text { Ig heavy chain } \mathrm{V}-\mathrm{III} \\
\text { region } \mathrm{BUT}\end{array}$ & 10.5 & 6.5 & 14.5 & 1.62 & -1.38 & 0.030 & 0.030 \\
\hline P01597 & $\begin{array}{l}\text { Ig kappa chain V-I } \\
\text { region DEE }\end{array}$ & 13.5 & 7.5 & 8 & 1.8 & 1.69 & 0.063 & 0.008 \\
\hline B9A064 & $\begin{array}{l}\text { Immunoglobulin } \\
\text { lambda-like } \\
\text { polypeptide } 5\end{array}$ & 143.5 & 87 & 104.5 & 1.65 & 1.37 & 0.091 & 0.008 \\
\hline P02788 & Lactotransferrin (LTF) & 15 & 1 & 3.5 & 15 & 4.29 & $<0.001$ & 0.009 \\
\hline P61626 & Lysozyme C (LYZ) & 13 & 8.5 & 6.5 & 1.53 & 2 & 0.061 & 0.04 \\
\hline P07737 & Profilin-1 (PFN1) & 29 & 15 & 22 & 1.93 & 1.32 & 0.025 & 0.02 \\
\hline P98160 & $\begin{array}{c}\text { Basement } \\
\text { membrane-specific } \\
\text { heparan sulfate } \\
\text { proteoglycan core } \\
\text { protein (HSPG2) }\end{array}$ & 13 & 8 & 6 & 1.63 & 2.17 & 0.155 & 0.038 \\
\hline P04220 & $\begin{array}{l}\text { Ig mu heavy chain } \\
\text { disease protein }\end{array}$ & 61.5 & 39 & 16 & 1.58 & 3.84 & 0.118 & 0.03 \\
\hline P01620 & $\begin{array}{l}\text { Ig kappa chain V-III } \\
\text { region SIE }\end{array}$ & 36.5 & 23.5 & 27.5 & 1.55 & 1.33 & 0.143 & 0.006 \\
\hline
\end{tabular}


Table 3. Cont.

\begin{tabular}{|c|c|c|c|c|c|c|c|c|}
\hline $\begin{array}{l}\text { Accession } \\
\text { Number }\end{array}$ & Protein Description & $\begin{array}{l}\text { PSMs } \\
\text { STIR+ }\end{array}$ & $\begin{array}{l}\text { PSMs } \\
\text { STIR- }\end{array}$ & $\begin{array}{l}\text { PSMs } \\
\text { CTRL }\end{array}$ & $\begin{array}{l}\text { Fold Change } \\
\text { STIR+/STIR- }\end{array}$ & $\begin{array}{l}\text { Fold Change } \\
\text { STIR+/CTRL }\end{array}$ & $\begin{array}{c}p \text { Value } \\
\text { STIR+/STIR- }\end{array}$ & $\begin{array}{c}p \text { Value } \\
\text { STIR+/CTRL }\end{array}$ \\
\hline P05109 & $\begin{array}{c}\text { Protein S100-A8 } \\
\text { (S100A8) }\end{array}$ & 13.5 & 6.5 & 7.5 & 2.08 & 1.8 & 0.047 & 0.014 \\
\hline P01871 & $\begin{array}{c}\text { Ig mu chain } \mathrm{C} \text { region } \\
(\mathrm{IGHM})\end{array}$ & 85.5 & 56 & 23.5 & 1.53 & 3.64 & 0.176 & 0.048 \\
\hline P06702 & $\begin{array}{c}\text { Protein S100-A9 } \\
\text { (S100A9) }\end{array}$ & 17.5 & 10 & 11.5 & 1.75 & 1.52 & 0.022 & 0.014 \\
\hline P02766 & Transthyretin (TTR) & 126.5 & 77.5 & 101 & 1.63 & 1.25 & 0.004 & 0.005 \\
\hline O75112 & $\begin{array}{l}\text { LIM domain-binding } \\
\text { protein } 3 \text { (LDB3) }\end{array}$ & 1 & 9.5 & 29 & -9.5 & -29 & 0.02 & $<0.001$ \\
\hline P05976 & $\begin{array}{l}\text { Myosin light chain } \\
1 / 3 \text {, skeletal muscle } \\
\text { isoform (MYL1) }\end{array}$ & 1 & 19 & 19 & -19 & -19 & 0.007 & 0.001 \\
\hline Q96A32 & $\begin{array}{l}\text { Myosin regulatory } \\
\text { light chain 2, skeletal } \\
\text { muscle isoform } \\
\text { (MYLPF) }\end{array}$ & 1 & 23 & 25.5 & -23 & -25.5 & $<0.001$ & 0.031 \\
\hline Q9UKX2 & Myosin-2 (MYH2) & 8.67 & 143 & 192 & -16.5 & -22.15 & $<0.001$ & 0.03 \\
\hline P00441 & $\begin{array}{c}\text { Superoxide dismutase } \\
\text { [Cu-Zn] (SOD1) }\end{array}$ & 3.5 & 9 & 10 & -2.57 & -2.86 & 0.039 & 0.028 \\
\hline
\end{tabular}

Peptide spectrum matches (PSMs) of each protein were used for quantitative analysis and only proteins with $p$-value $\leq 0.05$ are shown. Proteins found significantly dysregulated also in DIA are highlighted.

\subsection{Targeted Proteomic Approach}

We analyzed a pool of all the digested peptides from STIR+ and STIR- muscles, identifying 515 proteins in total, and performed multiple reaction monitoring (MRM) targeted analysis choosing a list of proteins related with DUX4 expression [3] to be specifically selected by the instrument. Despite this targeted approach, none of these proteins could be identified in the microdialysates.

\subsection{Serum Analysis}

Approximately $70 \%$ of the albumin and IgG content was removed after column treatment. We were able to qualitatively identify 455 proteins in at least one subject of which 130 were found only in FSHD patients, 271 were in common between FSHD and controls and 54 were present only in controls (Figure 5A and Supplementary Table S8).

Expression analysis comparing FSHD serum samples against healthy controls showed 19 dysregulated proteins, CD5 antigen-like (O43866) being the most upregulated (1.6 foldchange) (Supplementary Table S9). The majority of the proteins found in the serum of FSHD patients were also present in the microdialysates ( $n=273$, Figure 5B). Among these 273,52 were present in at least one of the STIR+ microdialysate samples and were absent in the serum of controls, thus configuring potential circulating biomarkers of disease activity in FSHD. Among these 52 proteins, Dermcidin, S100-A8, and A9 were found to be upregulated in the microdialysates of 8/10 STIR+ muscles (Supplementary Figure S3). 

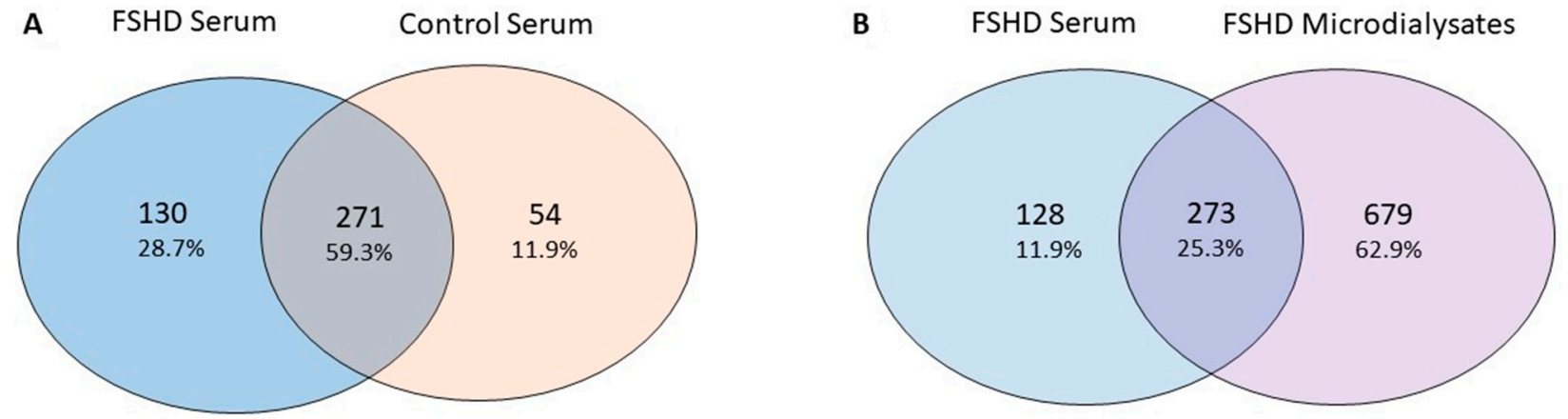

Figure 5. Overlaps of proteins identified in the serum. (A) Overlap between proteins identified in FSHD and healthy control sera after albumin and IgG/IgM removal. (B) Overlap between proteins identified in FSHD patients' sera and microdialysates.

\section{Discussion}

Biomarker identification is crucial both in the perspective of forthcoming clinical trials in FSHD and also to shed more light on the still elusive pathomechanisms taking place in vivo in this disease. Circulating biomarkers can represent an ideal index to monitor overall disease progression, in accordance with the concept of "liquid biopsies". Liquid chromatography-mass spectrometry (LC-MS) has been largely used for biomarker investigation, thanks to its capacity to identify and quantify large numbers of proteins with great accuracy. Many studies using proteomic approaches identified possible biomarkers for cancer, neurodegenerative diseases as well as muscular dystrophies [13]. In this context, this is the first study to examine microdialysates from patients' muscles stratified by MRI using a bottom-up proteomic approach. We found that most of the proteins in peripheral blood were also present in the microdialysates, confirming their secretory origin from skeletal muscle, which represents the most abundant tissue of our body, and in accordance with a recent proteomic profiling of DUX4 overexpressing cells that showed an upregulation of pathways related to exocytosis [14].

Compared with capture-based strategies, LC-MS has the advantage of truly hypothesisfree biomarker discovery [15]. On the other hand, a potential disadvantage is that peptides from highly abundant proteins can mask or interfere with peptides from less abundant proteins, thus decreasing the sensitivity of the assay [16]. However, the significant number of identified peptides in our study demonstrates that LC-MS can outperform multiplex targeted techniques [6].

Aiming to further increase the reliability of the data we chose to validate our results in two different mass spectrometry (MS) platforms. This strategy was used since the DDA mode provides a selective, quantitative and sensitive analysis by selecting peaks with higher intensity in each MS cycle and submitting them to a subsequent fragmentation. The principal advantage of this method is represented by the high accuracy for selected parent ions at the expense of a lack of acquisition of proteins excluded from this transition list. Orbitrap technology has the additional advantage of being commonly used also because of an easier MS/MS spectra interpretation [17]. The overlap between DDA and DIA approaches using two different MS platforms argues in favor of a good accuracy and reproducibility of the results.

Consistently with the presence of early damage in STIR+ muscles, most of the structural muscle proteins were downregulated in these samples. Other proteins found modulated in STIR+ muscles, such as Carbonic anhydrase 1 and 2, Neutrophil Defensin 1 and 3 , and proteins involved in complement system/innate immune response activation (Table 2), have been already described as dysregulated and possibly linked with FSHD pathophysiology [6,11].

We also report that S100-A8, S100-A9, Dermcidin and Insulin-growth factor-binding 4 were significantly (more than 50\%) upregulated in STIR+ muscles compared with STIR, together with Prostaglandin-H2 D-isomerase. The latter catalyzes the conversion of 
Prostaglandin-H2 to Prostaglandin-D2, a prostaglandin that has been found in Duchenne muscular dystrophy patients associated with muscle necrosis; assessment of its metabolites in urines has been proposed as a biomarker of progression in that disease [18]. Interestingly, S100-A8 and A9 and Dermcidin were found consistently upregulated in the samples of STIR+ muscles both by DIA and DDA. S100-A8 and A9 are calcium binding proteins actively secreted by myeloid cells (both neutrophils and monocytes), supposed to play a pivotal role in the pathogenesis of rheumatoid arthritis, inflammatory bowel disease and cystic fibrosis $[19,20]$. They constitute a heterodimer, also known as calprotectin, which may act as a damage-associated molecular pattern (DAMP) [21] able to activate innate immune pathways through stimulation of Toll-like receptor 4, therefore constituting a key molecule to trigger stress and inflammatory responses also in cancer [22]. S100-A8 and A9 have been reported as potential biomarkers in systemic autoimmune diseases [23], and given their function in the amplification of the inflammatory cascade could also constitute a possible therapeutic target. Notably, S100-A8 and Prostaglandin-H2 D-isomerase have been recently found significantly upregulated in the blood of early-onset FSHD patients compared with controls by LC-MS. For S100-A8, the finding was also confirmed by enzyme-linked immunosorbent assay [7].

Dermcidin is instead secreted by sweat glands on the skin, where it exerts antimicrobial activity. However, it is also secreted by skeletal muscle and the full-length protein promotes apoptosis under hypoxic conditions [24], while proteolytic fragments have the opposite role of promoting cancer cell survival in stress conditions [25]. Dermcidin has also recently been proposed as a prognostic biomarker of lung cancer together with S100-A9 [26].

Transcriptional upregulation of complement genes was one of the major findings in STIR+ muscles in two MRI targeted studies [12,27]. At protein level, complement system was among the top canonical dysregulated pathways in the extracellular fluid and we found consistently higher levels of complement factor D in both STIR+ and STIR- muscles compared to controls. Complement factor D activates $\mathrm{C} 3 \mathrm{~b}$ through the binding with factor $\mathrm{B}$ in the antibody independent, alternative complement pathway [28].

Plasminogen-like protein B, Plasminogen, and Vitronectin were found to be downregulated in STIR+ muscles (Table 2 and Supplementary Table S6), consistently with an overall downregulation of the plasminogen pathway. Indeed, plasminogen system activation has a proteolytic role in the extracellular matrix which is instrumental for muscle regeneration [28,29]. A perturbation in the delicate balance of inflammatory response and extracellular matrix remodeling, that provides the scaffold for the formation of new myofibers, might contribute to an impairment in the regenerative capacity in FSHD and eventually to the accumulation of fibrotic tissue. Concordantly, myogenic factors like MYOD1 and its target MEF2C are predicted to be inhibited in FSHD muscles, as previously reported in early microarray studies [30]. Vitronectin interacts directly and indirectly with plasminogen but also bridges it with complement, being one of the main inhibitors of the terminal pathway of the complement system [30,31]. Finally, Protein AMBP, that was found $\sim 2$ times more expressed in STIR+ samples when compared with control samples, can inhibit plasmin, which is the major enzyme responsible for the dissolution of fibrin as well as components of the extracellular matrix [32].

IPA highlighted an upstream activation of the MRTF/SRF axis in STIR- samples when compared to STIR+. MRTF-A and B interact with SRF and are involved in several cellular processes including skeletal muscle development and myogenic differentiation [33], and a downregulation of the MRTF/SRF signaling pathway is present in muscle atrophy secondary to disuse [34]. The (partial) shutdown of this pathway in STIR+ muscles could be also consistent with a deficiency of regenerative capacity in affected FSHD muscles [35]. IPA further confirmed a perturbation in humoral immune response, immune cell trafficking and tissue development in STIR+ muscles.

We also provide preliminary evidence of protein modulation in FSHD sera applying the same MS protocol used for the microdialysates. CD5 antigen-like was found in the samples of all the patients significantly upregulated compared with controls. It is a key 
regulator of intracellular lipid synthesis and, notably, is mainly expressed by macrophages in lymphoid and inflamed tissues where it regulates several processes including fibrosis [36]. It has also been proposed as a biomarker in a number of inflammatory [36,37] and neoplastic conditions [38].

Among the other proteins that were present in the serum of at least one patient and absent in controls, three (S100-A8, A9 and Dermcidin) could be identified in $80 \%$ of the analyzed microdialysates derived from STIR+ muscles. Given that these proteins were also consistently present among the most upregulated in STIR+ muscles with both types of proteomic analysis implemented, they configure the strongest candidates as circulating biomarkers of disease activity identified with our study.

Our study has some limitations. The first one is related to its exploratory nature on a small number of patients and to the very small amounts of interstitial fluid available [11], thus providing results that need to be confirmed on larger numbers and with different methods. The second one is constituted by the filter applied on the microdialysis membrane, whose cut-off could affect the recovery of potential biomarkers with higher molecular weight. The third is an intrinsic drawback of the proteomic approach when dealing with sera, where target proteins are diluted and suffer from a possible ion suppression by the most abundant proteins.

\section{Materials and Methods}

\subsection{Patients and Samples}

Patients were consecutively enrolled during the MRI follow-up in the period April 2014-February 2016, corresponding to the time window of our previous study [11]. Briefly, patients had to have one externally accessible lower limb muscle showing normal signal on T1-weighted MRI sequences and hyperintense signal on STIR sequences, i.e., one muscle showing edema changes but not yet replaced by fat tissue, together with the contralateral muscle showing normal signal on both T1-weighted and STIR sequences. FSHD patients underwent microdialysis on the identified STIR+ and STIR- muscles at the same time, while only one muscle was studied for controls and NPGC. Subjects with concomitant systemic inflammatory diseases or under treatment with anti-inflammatory drugs were excluded. We collected microdialysis and blood samples from 10 genetically confirmed typical FSHD patients ( 5 females and 5 males, mean age $41.7 \pm 13.4$, range 18-58), 4 controls ( 3 males and 1 female, mean age $41.5 \pm 16.4$ years, range 24-60) and one NPGC (female, age 47). Controls were healthy subjects who volunteered to undergo the microdialysis procedure, including unaffected relatives of FSHD patients, with age $>18$ and $<65$ years, and no systemic inflammatory disease. Clinical and genetic data of all subjects is reported in Table 4 . The microdialysates selected for proteomic analysis were obtained at comparable time points between 48 and $56 \mathrm{~h}$ post catheter insertion.

Table 4. Summary of clinical and genetic data.

\begin{tabular}{ccccccccccc}
\hline Pt ID & Dx & Age & Sex & EcoRI & CSS & Muscle & $\begin{array}{c}\text { Age at } \\
\text { Onset }\end{array}$ & $\begin{array}{c}\text { Symptoms } \\
\text { at Onset }\end{array}$ & $\begin{array}{c}\text { Treatment } \\
\text { History }\end{array}$ \\
\hline p2 & CTRL & 24 & M & N.P. & 0 & Vastus lateralis & N.A. & N.A. & None & Unremarkable \\
\hline p4 & FSHD & 43 & F & 17 & 3 & $\begin{array}{c}\text { Gastrocnemius } \\
\text { lateralis }\end{array}$ & $\begin{array}{c}\text { Second } \\
\text { decade }\end{array}$ & $\begin{array}{c}\text { Scapular } \\
\text { winging }\end{array}$ & Levothyroxine Hypothyroidism \\
\hline p5 & FSHD & 53 & F & 24 & 3.5 & Peroneus & $\begin{array}{c}\text { Second } \\
\text { decade }\end{array}$ & $\begin{array}{c}\text { Scapular } \\
\text { winging }\end{array}$ Levothyroxine Hypothyroidism \\
\hline p6 & FSHD & 55 & F & 15 & 3.5 & Vastus lateralis & $\begin{array}{c}\text { Second } \\
\text { decade }\end{array}$ & $\begin{array}{c}\text { Scapular } \\
\text { winging }\end{array}$ & $\begin{array}{c}\text { Amlodipine, } \\
\text { bisoprolol, } \\
\text { hydrochloroth- Hypertension } \\
\text { iazide }\end{array}$ \\
\hline
\end{tabular}


Table 4. Cont.

\begin{tabular}{|c|c|c|c|c|c|c|c|c|c|c|}
\hline Pt ID & Dx & Age & Sex & EcoRI & CSS & Muscle & $\begin{array}{l}\text { Age at } \\
\text { Onset }\end{array}$ & $\begin{array}{l}\text { Symptoms } \\
\text { at Onset }\end{array}$ & Treatment & $\begin{array}{c}\text { Past Medical } \\
\text { History }\end{array}$ \\
\hline p7 & FSHD & 29 & M & 20 & 2.5 & $\begin{array}{l}\text { Biceps femoris } \\
\text { short head }\end{array}$ & $\begin{array}{l}\text { Second } \\
\text { decade }\end{array}$ & $\begin{array}{c}\text { Difficulty } \\
\text { in raising } \\
\text { arms }\end{array}$ & None & Unremarkable \\
\hline $\mathrm{p} 8$ & FSHD & 18 & $\mathrm{M}$ & 23 & 1.5 & Semimembranosus & $\begin{array}{l}\text { Second } \\
\text { decade }\end{array}$ & $\begin{array}{c}\text { Difficulty } \\
\text { in raising } \\
\text { arms }\end{array}$ & None & Unremarkable \\
\hline p9 & NPGC & 47 & $\mathrm{~F}$ & 33 & 0 & Vastus lateralis & N.A. & N.A. & None & Headache \\
\hline p10 & FSHD & 44 & M & 25 & 3.5 & $\begin{array}{l}\text { Gastrocnemius } \\
\text { lateralis }\end{array}$ & $\begin{array}{l}\text { Fourth } \\
\text { decade }\end{array}$ & $\begin{array}{l}\text { Scapular } \\
\text { winging }\end{array}$ & None & Unremarkable \\
\hline p11 & FSHD & 58 & $\mathrm{~F}$ & 23 & 3 & Gracilis & $\begin{array}{l}\text { Second } \\
\text { decade }\end{array}$ & $\begin{array}{c}\text { Difficulty } \\
\text { in raising } \\
\text { arms }\end{array}$ & Cholecalciferol & Osteoporosis \\
\hline p12 & FSHD & 53 & M & 24 & 3 & $\begin{array}{c}\text { Extensor } \\
\text { digitorum longus }\end{array}$ & $\begin{array}{c}\text { Fifth } \\
\text { decade }\end{array}$ & $\begin{array}{l}\text { Scapular } \\
\text { winging }\end{array}$ & None & Unremarkable \\
\hline p13 & CTRL & 60 & M & $>40$ & 0 & Vastus lateralis & N.A. & N.A. & None & Unremarkable \\
\hline p14 & CTRL & 50 & M & $>40$ & 0 & Vastus lateralis & N.A. & N.A. & None & Unremarkable \\
\hline p15 & FSHD & 34 & M & 19 & 3 & Semitendinosus & $\begin{array}{l}\text { Third } \\
\text { decade }\end{array}$ & $\begin{array}{c}\text { Facial } \\
\text { weakness }\end{array}$ & None & Unremarkable \\
\hline p17 & FSHD & 30 & $\mathrm{~F}$ & 18 & 3 & Tibialis anterior & $\begin{array}{l}\text { Second } \\
\text { decade }\end{array}$ & $\begin{array}{l}\text { Scapular } \\
\text { winging }\end{array}$ & None & Unremarkable \\
\hline p18 & CTRL & 32 & $\mathrm{~F}$ & N.P. & 0 & Vastus lateralis & N.A. & N.A. & None & Unremarkable \\
\hline
\end{tabular}

This protocol is in agreement with the Declaration of Helsinki and was approved by the Ethics Committee of our Institution. All the involved subjects gave their written informed consent prior to the inclusion in the study.

\subsection{Mass Spectrometry Based Proteomic Analysis}

The label free shotgun proteomic analysis was performed using two different experimental setups: DIA performed on a Synapt G2-Si Q-TOF mass spectrometer with T Wave cell for ion mobility separation (Waters Corp.), and DDA, performed on a Orbitrap Elite mass spectrometer (Thermo) [39].

\subsection{Synapt G2Si-Proteomic Analysis}

Twenty-five microdialysis samples from 10 FSHD patients (simultaneously obtained from 10 STIR+ and 10 contralateral STIR- muscles), 4 controls and the NPGC were quantified using the Bio-Rad Protein Assay method and had an average protein concentration of approximately $0.5 \mu \mathrm{g} / \mu \mathrm{L}$. To minimize the problem of the low volume and protein concentration, we applied the filter-aided sample preparation (FASP) protocol [40]. For the FASP protocol we made use of a microcolumn tip with 10kDa molecular weight cut-off (MWCO). Ten micrograms of protein amount were diluted into a final volume of $100 \mu \mathrm{L}$ in Tris-Urea Buffer (Tris- $\mathrm{HCl} 100 \mathrm{mM} \mathrm{pH} 7.5$; Urea 6M) and applied in the column for further reduction, alkylation and trypsin digestion.

Serum samples were first desalted in a spin filter column (Vivaspin 3000 Da MWCO): $250 \mu \mathrm{L}$ of each sample were added into a spin filter and centrifuged for $60 \mathrm{~min}$ at $5000 \mathrm{~g}$, and the material retained in the filter was used to perform Albumin and IgG/IgM removal (Pierce Albumin/IgG removal Kit, Thermo Scientific) according to the manufacturer's instructions. After the process of desalination and removal of Albumin and IgG, the leftover 
proteins were washed, and the two fractions were later submitted to the same digestion protocol already mentioned.

The peptides obtained were submitted to a LC-MS analysis, using a High Definition Synapt G2-Si mass spectrometer directly coupled to the chromatographic system. For each sample the same amount of digested peptides was analyzed. Continuum LC-MS data from three replicate runs for each were processed for qualitative and quantitative analysis using the software ProteinLynx Global Server v. 3.0.3 (PLGS, Waters Corp.) [41].

\subsection{Orbitrap Elite Proteomic Analysis}

Protein concentration of 3 microdialysates for each condition (STIR+ and STIR- muscles from P7, P8, and P10, and controls P13, P14, and P18, selected based on the amount of microdialysate material left after previous analyses) was assayed by Bio-Rad Protein Assay and $7.6 \mu \mathrm{g}$ were used for further processing. To reduce the impact of the most abundant proteins, a fractionation method was carried out [42].

Additional details about MS instrument settings, statistical analysis, label free quantification, MRM, network analysis, and heatmap building are available as Supplementary Methods.

\section{Conclusions}

Our pilot study proved that high-resolution proteomics is a feasible method to analyze muscle microdialysates, and that proteomic profiles of interstitial muscle fluids are able to distinguish FSHD patients from controls. The modulation of protein expression in FSHD muscles with signs of early damage showed the activation of pathways related to inflammation, which further supports the role of this process in active disease phases, and a lack of regenerative capacity. We propose a "protein signature" associated with active disease constituted by the downregulation of structural muscle proteins and upregulation of Dermcidin, S100-A8, and A9.

Supplementary Materials: Supplementary materials can be found at https://www.mdpi.com/1422 -0067/22/1/290/s1. Supplementary methods, Tables S1-S9, Figures S1-S3. The mass spectrometry proteomics data have been deposited to the ProteomeXchange Consortium via the PRIDE [43] partner repository with the dataset identifier PXD021838.

Author Contributions: Conceptualization, E.R. and G.T.; methodology, M.M., G.T., G.D.M., V.C.C., A.U. and L.P.; formal analysis G.D.M., M.M. and V.C.C.; investigation, M.M., G.T., G.D.M. and V.C.C.; resources, G.T.; data curation, V.C.C. and G.D.M.; writing-original draft preparation, V.C.C. and G.T.; writing-review and editing, M.M., G.D.M., L.P., A.U. and E.R.; supervision, A.U., E.R., L.P. and G.T.; project administration, G.T.; funding acquisition, G.T. All authors have read and agreed to the published version of the manuscript.

Funding: This study was funded by the FSHD Society Grant FSHS-82017-6 to G.T.

Institutional Review Board Statement: The study was conducted according to the guidelines of the Declaration of Helsinki, and approved by Ethics Committee of the Università Cattolica del Sacro Cuore (protocol code P/279/CE/2009, 26 March 2009).

Informed Consent Statement: Informed consent was obtained from all subjects involved in the study.

Data Availability Statement: The data that support the findings of this study are available from the corresponding author upon reasonable request.

Conflicts of Interest: The authors declare no conflict of interest. The funders had no role in the design of the study; in the collection, analyses, or interpretation of data; in the writing of the manuscript, or in the decision to publish the results. 


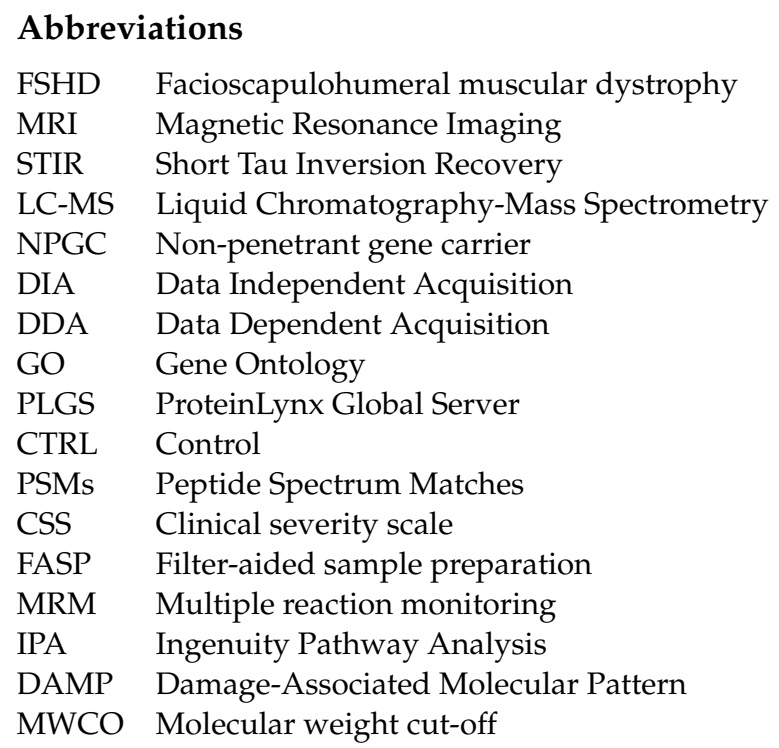

\section{References}

1. Padberg, G.W.; Lunt, P.W.; Koch, M.; Fardeau, M. Diagnostic criteria for facioscapulohumeral muscular dystrophy. Neuromuscul. Disord. 1991, 1, 231-234. [CrossRef]

2. Snider, L.; Geng, L.N.; Lemmers, R.J.L.F.; Kyba, M.; Ware, C.B.; Nelson, A.M.; Tawil, R.; Filippova, G.N.; van der Maarel, S.M.; Tapscott, S.J.; et al. Facioscapulohumeral dystrophy: Incomplete suppression of a retrotransposed gene. PLoS Genet. 2010, 6, e1001181. [CrossRef] [PubMed]

3. Geng, L.N.; Yao, Z.; Snider, L.; Fong, A.P.; Cech, J.N.; Young, J.M.; van der Maarel, S.M.; Ruzzo, W.L.; Gentleman, R.C.; Tawil, R.; et al. DUX4 activates germline genes, retroelements, and immune mediators: Implications for facioscapulohumeral dystrophy. Dev. Cell 2012, 22, 38-51. [CrossRef] [PubMed]

4. Kissel, J.T.; McDermott, M.P.; Natarajan, R.; Mendell, J.R.; Pandya, S.; King, W.M.; Griggs, R.C.; Tawil, R.; FSH—Dy Group. Pilot trial of albuterol in facioscapulohumeral muscular dystrophy. Neurology 1998, 50, 1402-1406. [CrossRef]

5. Statland, J.; Donlin-Smith, C.M.; Tapscott, S.J.; van der Maarel, S.; Tawil, R. Multiplex screen of serum biomarkers in facioscapulohumeral muscular dystrophy. J. Neuromuscul. Dis. 2014, 1, 181-190. [CrossRef]

6. $\quad$ Petek, L.M.; Rickard, A.M.; Budech, C.; Poliachik, S.L.; Shaw, D.; Ferguson, M.R.; Tawil, R.; Friedman, S.D.; Miller, D.G. A cross sectional study of two independent cohorts identifies serum biomarkers for facioscapulohumeral muscular dystrophy (FSHD). Neuromuscul. Disord. 2016, 26, 405-413. [CrossRef]

7. Heier, C.R.; Zhang, A.; Nguyen, N.Y.; Tully, C.B.; Panigrahi, A.; Gordish-Dressman, H.; Pandey, S.P.; Guglieri, M.; Ryan, M.M.; Clemens, P.R.; et al. Multi-omics identifies circulating miRNA and protein biomarkers for facioscapulohumeral dystrophy. J. Pers. Med. 2020, 10, 236. [CrossRef]

8. Tasca, G.; Monforte, M.; Ottaviani, P.; Pelliccioni, M.; Frusciante, R.; Laschena, F.; Ricci, E. Magnetic resonance imaging in a large cohort of facioscapulohumeral muscular dystrophy patients: Pattern refinement and implications for clinical trials. Ann. Neurol. 2016, 79, 854-864. [CrossRef]

9. Monforte, M.; Laschena, F.; Ottaviani, P.; Bagnato, M.R.; Pichiecchio, A.; Tasca, G.; Ricci, E. Tracking muscle wasting and disease activity in facioscapulohumeral muscular dystrophy by qualitative longitudinal imaging. J. Cachexia Sarcopenia Muscle 2019, 10, 1258-1265. [CrossRef]

10. Tawil, R.; Padberg, G.W.; Shaw, D.W.; van der Maarel, S.M.; Tapscott, S.J.; FSHD Workshop Participants. Clinical trial preparedness in facioscapulohumeral muscular dystrophy: Clinical, tissue, and imaging outcome measures 29-30 May 2015, Rochester, New York. Neuromuscul. Disord. 2016, 26, 181-186. [CrossRef]

11. Tasca, G.; Monforte, M.; Corbi, M.; Granata, G.; Lucchetti, D.; Sgambato, A.; Ricci, E. Muscle microdialysis to investigate inflammatory biomarkers in facioscapulohumeral muscular dystrophy. Mol. Neurobiol. 2018, 55, 2959-2966. [CrossRef] [PubMed]

12. Tasca, G.; Pescatori, M.; Monforte, M.; Mirabella, M.; Iannaccone, E.; Frusciante, R.; Cubeddu, T.; Laschena, F.; Ottaviani, P.; Ricci, E. Different molecular signatures in magnetic resonance imaging-staged facioscapulohumeral muscular dystrophy muscles. PLoS ONE 2012, 7, e38779. [CrossRef] [PubMed]

13. Shi, T.; Song, E.; Nie, S.; Rodland, K.D.; Liu, T.; Qian, W.-J.; Smith, R.D. Advances in targeted proteomics and applications to biomedical research. Proteomics 2016, 16, 2160-2182. [CrossRef] [PubMed]

14. Jagannathan, S.; Ogata, Y.; Gafken, P.R.; Tapscott, S.J.; Bradley, R.K. Quantitative proteomics reveals key roles for posttranscriptional gene regulation in the molecular pathology of facioscapulohumeral muscular dystrophy. Elife 2019, 8. [CrossRef]

15. Carlyle, B.; Trombetta, B.; Arnold, S. Proteomic approaches for the discovery of biofluid biomarkers of neurodegenerative dementias. Proteomes 2018, 6, 32. [CrossRef] 
16. Sandberg, A.; Branca, R.M.M.; Lehtiö, J.; Forshed, J. Quantitative accuracy in mass spectrometry based proteomics of complex samples: The impact of labeling and precursor interference. J. Proteom. 2014, 96, 133-144. [CrossRef]

17. Vidova, V.; Spacil, Z. A review on mass spectrometry-based quantitative proteomics: Targeted and data independent acquisition. Anal. Chim. Acta 2017, 964, 7-23. [CrossRef]

18. Takeshita, E.; Komaki, H.; Tachimori, H.; Miyoshi, K.; Yamamiya, I.; Shimizu-Motohashi, Y.; Ishiyama, A.; Saito, T.; Nakagawa, E.; Sugai, K.; et al. Urinary prostaglandin metabolites as Duchenne muscular dystrophy progression markers. Brain Dev. 2018, 40, 918-925. [CrossRef]

19. Austermann, J.; Spiekermann, C.; Roth, J. S100 proteins in rheumatic diseases. Nat. Rev. Rheumatol. 2018, 14, 528-541. [CrossRef]

20. Khaki-Khatibi, F.; Qujeq, D.; Kashifard, M.; Moein, S.; Maniati, M.; Vaghari-Tabari, M. Calprotectin in inflammatory bowel disease. Clin. Chim Acta 2020, 510, 556-565. [CrossRef]

21. Crowe, L.A.N.; McLean, M.; Kitson, S.M.; Melchor, E.G.; Patommel, K.; Cao, H.M.; Reilly, J.H.; Leach, W.J.; Rooney, B.P.; Spencer, S.J.; et al. S100A8 \& S100A9: Alarmin mediated inflammation in tendinopathy. Sci. Rep. 2019, 9, 1463. [PubMed]

22. Ehrchen, J.M.; Sunderkötter, C.; Foell, D.; Vogl, T.; Roth, J. The endogenous Toll-like receptor 4 agonist S100A8/S100A9 (calprotectin) as innate amplifier of infection, autoimmunity, and cancer. J. Leukoc. Biol. 2009, 86, 557-566. [CrossRef] [PubMed]

23. Ometto, F.; Friso, L.; Astorri, D.; Botsios, C.; Raffeiner, B.; Punzi, L.; Doria, A. Calprotectin in rheumatic diseases. Exp. Biol. Med. 2017, 242, 859-873. [CrossRef] [PubMed]

24. Esposito, G.; Schiattarella, G.G.; Perrino, C.; Cattaneo, F.; Pironti, G.; Franzone, A.; Gargiulo, G.; Magliulo, F.; Serino, F.; Carotenuto, G.; et al. Dermcidin: A skeletal muscle myokine modulating cardiomyocyte survival and infarct size after coronary artery ligation. Cardiovasc. Res. 2015, 107, 431-441. [CrossRef]

25. Stewart, G.D.; Skipworth, R.J.; Ross, J.A.; Fearon, K.C.; Baracos, V.E. The dermcidin gene in cancer: Role in cachexia, carcinogenesis and tumour cell survival. Curr. Opin. Clin. Nutr. Metab. Care 2008, 11, 208-213. [CrossRef]

26. Núñez-Naveira, L.; Mariñas-Pardo, L.A.; Montero-Martínez, C. Mass spectrometry analysis of the exhaled breath condensate and proposal of dermcidin and S100A9 as possible markers for lung cancer prognosis. Lung 2019, 197, 523-531. [CrossRef]

27. Wang, L.H.; Friedman, S.D.; Shaw, D.; Snider, L.; Wong, C.-J.; Budech, C.B.; Poliachik, S.L.; Gove, N.E.; Lewis, L.M.; Campbell, A.E.; et al. MRI-informed muscle biopsies correlate MRI with pathology and DUX4 target gene expression in FSHD. Hum. Mol. Genet. 2019, 28, 476-486. [CrossRef]

28. Vignesh, P.; Rawat, A.; Sharma, M.; Singh, S. Complement in autoimmune diseases. Clin. Chim. Acta 2017, 465, 123-130. [CrossRef]

29. Suelves, M.; Vidal, B.; Ruiz, V.; Baeza-Raja, B.; Diaz-Ramos, A.; Cuartas, I.; Lluis, F.; Parra, M.; Jardi, M.; Lopez-Alemany, R.; et al. The plasminogen activation system in skeletal muscle regeneration: Antagonistic roles of urokinase-type plasminogen activator (uPA) and its inhibitor (PAI-1). Front. Biosci. 2005, 10, 2978-2985. [CrossRef]

30. Celegato, B.; Capitanio, D.; Pescatori, M.; Romualdi, C.; Pacchioni, B.; Cagnin, S.; Viganò, A.; Colantoni, L.; Begum, S.; Ricci, E.; et al. Parallel protein and transcript profiles of FSHD patient muscles correlate to the D4Z4 arrangement and reveal a common impairment of slow to fast fibre differentiation and a general deregulation of MyoD-dependent genes. Proteomics 2006, 6, 5303-5321. [CrossRef]

31. Lepedda, A.J.; Deiana, G.A.; Lobina, O.; Nieddu, G.; Baldinu, P.; De Muro, P.; Andreetta, F.; Sechi, E.; Arru, G.; Corda, D.G.; et al. Plasma vitronectin is reduced in patients with myasthenia gravis: Diagnostic and pathophysiological potential. J. Circ. Biomark 2019, 8, 1849454419875912. [CrossRef] [PubMed]

32. Irigoyen, J.P.; Muñoz-Cánoves, P.; Montero, L.; Koziczak, M.; Nagamine, Y. The plasminogen activator system: Biology and regulation. Cell. Mol. Life Sci. 1999, 56, 104-132. [CrossRef] [PubMed]

33. Cenik, B.K.; Liu, N.; Chen, B.; Bezprozvannaya, S.; Olson, E.N.; Bassel-Duby, R. Myocardin-related transcription factors are required for skeletal muscle development. Development 2016, 143, 2853-2861. [CrossRef] [PubMed]

34. Collard, L.; Herledan, G.; Pincini, A.; Guerci, A.; Randrianarison-Huetz, V.; Sotiropoulos, A. Nuclear actin and myocardin-related transcription factors control disuse muscle atrophy through regulation of SRF activity. J. Cell Sci. 2014, 127, 5157-5163. [CrossRef]

35. Morosetti, R.; Mirabella, M.; Gliubizzi, C.; Broccolini, A.; Sancricca, C.; Pescatori, M.; Gidaro, T.; Tasca, G.; Frusciante, R.; Tonali, P.A.; et al. Isolation and characterization of mesoangioblasts from facioscapulohumeral muscular dystrophy muscle biopsies. Stem Cells 2007, 25, 3173-3182. [CrossRef]

36. Bárcena, C.; Aran, G.; Perea, L.; Sanjurjo, L.; Téllez, É.; Oncins, A.; Masnou, H.; Serra, I.; García-Gallo, M.; Kremer, L.; et al. CD5L is a pleiotropic player in liver fibrosis controlling damage, fibrosis and immune cell content. EBioMedicine 2019, 43, 513-524. [CrossRef]

37. Sanjurjo, L.; Amézaga, N.; Aran, G.; Naranjo-Gómez, M.; Arias, L.; Armengol, C.; Borràs, F.E.; Sarrias, M.-R. The human CD5L/AIM-CD36 axis: A novel autophagy inducer in macrophages that modulates inflammatory responses. Autophagy 2015, 11, 487-502. [CrossRef]

38. Zografos, E.; Anagnostopoulos, A.K.; Papadopoulou, A.; Legaki, E.; Zagouri, F.; Marinos, E.; Tsangaris, G.T.; Gazouli, M. Serum proteomic signatures of male breast cancer. Cancer Genom. Proteom. 2019, 16, 129-137. [CrossRef]

39. Marini, F.; Carregari, V.C.; Greco, V.; Ronci, M.; Iavarone, F.; Persichilli, S.; Castagnola, M.; Urbani, A.; Pieroni, L. Exploring the hela dark mitochondrial proteome. Front. Cell Dev. Biol 2020, 8, 137. [CrossRef]

40. Distler, U.; Kuharev, J.; Navarro, P.; Tenzer, S. Label-free quantification in ion mobility-enhanced data-independent acquisition proteomics. Nat. Protoc. 2016, 11, 795-812. [CrossRef] 
41. Silva, J.C.; Gorenstein, M.V.; Li, G.-Z.; Vissers, J.P.C.; Geromanos, S.J. Absolute quantification of proteins by LCMSE: A virtue of parallel MS acquisition. Mol. Cell. Proteom. 2006, 5, 144-156. [CrossRef] [PubMed]

42. Liu, G.; Zhao, Y.; Angeles, A.; Hamuro, L.L.; Arnold, M.E.; Shen, J.X. A novel and cost effective method of removing excess albumin from plasma/serum samples and its impacts on LC-MS/MS bioanalysis of therapeutic proteins. Anal. Chem. 2014, 86, 8336-8343. [CrossRef] [PubMed]

43. Perez-Riverol, Y.; Csordas, A.; Bai, J.; Bernal-Llinares, M.; Hewapathirana, S.; Kundu, D.J.; Inuganti, A.; Griss, J.; Mayer, G.; Eisenacher, M.; et al. The PRIDE database and related tools and resources in 2019: Improving support for quantification data. Nucleic Acids Res. 2019, 47, D442-D450. [CrossRef] [PubMed] 